\title{
Lung Fluid Dynamics in Awake Newborn Lambs
}

\author{
RichaRd D. Bland and Douglas D. McMillan, The Cardiovascular \\ Research Institute and the Department of Pediatrics, University of \\ California, San Francisco, California 94143
}

A B S T RACT We measured steady-state lung lymph flow, lymph protein flow, and simultaneous pulmonary vascular pressures in 12 1-wk-old unanesthetized lambs and compared these measurements to those of previous studies, performed under similar conditions, on nine awake adult sheep. The purpose of these experiments was to compare newborn and adult sheep with respect to transvascular filtration of fluid and microvascular permeability to plasma proteins. We prepared the lambs surgically to isolate and collect lung lymph and measure average pulmonary arterial and left atrial pressures, allowing at least 2 days for the lambs to recover from surgery before studies began. Lambs had higher pulmonary arterial and left atrial pressures, lower lymph and plasma protein concentrations, and $57 \%$ more lymph flow per gram of dry bloodless lung than sheep; the difference in protein flow between lambs and sheep was not significant. Protein concentration in lymph relative to that in plasma was significantly lower in lambs than in sheep; but the ratio of albumin concentration to globulin concentration in both lymph and plasma was almost identical in the two groups of animals. Extravascular lung water per gram of dry bloodless lung was greater in lambs $(4.82 \pm 0.11$ g) than in sheep $(4.45 \pm 0.08 \mathrm{~g})$, but there was no histologic evidence of pulmonary edema in either group of animals. These findings suggest that lambs have more transvascular filtration of fluid per unit lung mass than sheep, but that microvascular sites for protein exchange do not differ appreciably in lambs and sheep. To test this conclusion, we measured steady-state lymph flow in three lambs before and after raising pulmonary microvascular pressure by rapid intravenous infusion of saline. Lymph flow increased as a function of the net transvascular driving pressure (hydraulic pressure gradient-protein osmotic pressure gradient).

\footnotetext{
We presented part of this work to the American Pediatric Society and the Society for Pediatric Research in St. Louis, Mo., 30 April 1976, and at the 19th Aspen Lung Conference in Aspen, Colo., 10 June 1976.

Received for publication 6 July 1976 and in revised form 27 June 1977.
}

This response was almost identical to that of four sheep with pulmonary microvascular pressure augmented by inflation of a balloon in the left atrium. In eight lambs we measured the time for intravenously injected ${ }^{125} \mathrm{I}$ albumin to equilibrate in lymph at half the specific activity of plasma: the protein tag equilibrated faster than in sheep. This difference could be explained partly by the higher pulmonary arterial and left atrial pressures of lambs than sheep, and possibly by the presence of more microvascular sites for protein exchange relative to the volume of distribution of protein in the lung of the younger animals.

\section{INTRODUCTION}

For many years physiologists have suggested that microvascular permeability to plasma proteins in the lung is greater in newborn than in mature animals of the same species. Several reports during the past decade have supported that conclusion (1-5), but all derive from acute experiments carried out on anesthetized animals soon after extensive surgery, often after rapid infusions of saline, and frequently without consideration of pulmonary vascular hydraulic pressures.

We attempted to improve our understanding of lung fluid and protein dynamics in the newborn lamb by measuring lung lymph flow and protein flow, with simultaneous pulmonary vascular pressures, under steady-state conditions in 12 unanesthetized 7- to 14day-old lambs. We compared the results of these experiments to those of previous studies on adult sheep (6) and found that newborn lambs have higher average vascular pressures in the lung and greater pulmonary transvascular filtration of fluid per unit lung mass than adult sheep, without evidence of an appreciable difference in the dimensions of microvascular sites for protein exchange.

\section{METHODS}

Preparation for experiments. We surgically prepared 12 newborn lambs (average birth weight: $3.9 \mathrm{~kg}$; range: $2.6-$ $5.2 \mathrm{~kg}$ ), by a modification of the method described by Staub 
et al. (7), to isolate and collect lung lymph and measure average pulmonary arterial $(\overline{\mathrm{P}} \mathrm{pa})^{1}$ and left atrial ( $\mathrm{P}$ la) pressures. We performed two thoracotomies on each lamb, the first within $48 \mathrm{~h}$ after birth and the second 4-7 days later. The animals received nitrous oxide and halothane anesthesia and were ventilated with a volume respirator (Model 607, Harvard Apparatus Co. Inc., Millis, Mass.) during surgery. Before and after surgery and between experiments, the lambs remained with their ewes for feeding and warmth.

In the first operation, we placed polyvinyl catheters (Tygon Tubing, Akron, Ohio) in the thoracic aorta, both atria, and the pulmonary artery. After the lambs recovered from surgery, we did a second thoracotomy to obtain pulmonary lymph. In fetal and newborn lambs and adult sheep, close to two-thirds of the lung lymph flows into the thoracic duct by way of the caudal mediastinal lymph node $(3,8)$, which is a long, narrow structure located in the posterior mediastinum between the aorta and the esophagus on the right side of the chest. We ligated and severed the systemic contributions to that lymph node and inserted a heparinimpregnated polyvinyl catheter, internal diameter 0.011 or 0.015 inches, into the efferent duct of that node for collection of nearly pure pulmonary lymph. Previous studies on adult sheep demonstrated that this fluid is not contaminated appreciably by lymph of systemic origin (7). We tunneled the catheter beneath the pleura and brought it through the chest wall, securing it to the skin with a suture, and placed a polyvinyl catheter in the pleural space for postoperative drainage of pleural fluid and air. After surgery, we allowed the lambs at least 2 days to recover and did not begin experiments until the pleural cavity was free of fluid and the lymph contained no visible blood and was flowing at a steady rate.

Base-line experiments. The average weight of the lambs at the time of the experiments was $6.0 \mathrm{~kg}$ (range: $4.3-7.9 \mathrm{~kg}$ ). On each animal we did between one and four experiments on consecutive days. During experiments, the lambs remained without restraints in a cardboard box. We measured Ppa, Pla, and phasic aortic blood pressure continuously, using calibrated pressure transducers (Statham P23 Dc, Statham Instruments Div. Gould Inc., Oxnard, Calif.) and a fourchannel amplifier-recorder (Grass model 7B polygraph, 7 DA $\mathrm{E}$ amplifiers, and $7 \mathrm{Pl}$ B preamplifiers, Grass Instrument Co., Quincy, Mass.). The zero reference level for all pressure measurements was a line drawn on the lambs' skin at the level of the left atrium immediately after surgery. Before each experiment, we set and calibrated the transducers at the level of that line. We measured lymph flow to the nearest $0.01 \mathrm{ml}$ at 30 -min intervals for at least $2 \mathrm{~h}$ during a steadystate period and collected samples of lymph and blood in heparinized test tubes every $30 \mathrm{~min}$.

Saline-infusion experiments. After a steady-state base-line period in three lambs, we rapidly infused sterile saline, $154 \mathrm{meq} / \mathrm{l}$, into the right atrium at a constant rate of $130-250$ $\mathrm{ml} / \mathrm{kg}$ per $\mathrm{h}$ for $3-4 \mathrm{~h}$, thereby increasing Pिpa and $\bar{P} l a$ and lowering lymph and plasma concentrations of protein to new steady-state levels. We collected lymph and measured vascular pressures during these three experiments, which the animals tolerated well.

Tracer studies. In eight lambs we measured the time for intravascular ${ }^{125}$ I-albumin to equilibrate in lymph at half the specific activity of plasma. After collecting at least two baseline samples of lymph and blood, we injected ${ }^{125} \mathrm{I}$-albumin,

${ }^{1}$ Abbreviations used in this paper: $\overline{\mathrm{P}} \mathrm{pa}$, average pulmonary arterial pressure; Pla, average left atrial pressure; Qlym, lymph flow; Qpr, protein flow.
5-10 $\mu \mathrm{Ci} / \mathrm{kg}$ of lamb weight, into the right atrium, collected samples of lymph in heparinized test tubes over intervals of $15 \mathrm{~min}$ for $3 \mathrm{~h}$, and obtained blood samples at the midpoint of each 15-min collection period. We measured radioactivity, protein, and albumin concentrations on aliquots of these samples.

Postmortem studies. At the conclusion of the experiments on each animal, we injected sodium pentobarbital, $20 \mathrm{mg} / \mathrm{kg}$, and heparin into the right atrium, placed the lamb in the supine position, ventilated the lungs with $20 \mathrm{ml} / \mathrm{kg}$ of air via the Harvard respirator, and rapidly split the sternum to excise both lungs. We cross-clamped the hila of the lungs at end-inspiration with the heart still beating and removed the lungs for measurement of extravascular water and dry bloodless lung weight.

From four lambs we removed and quickly froze the inflated lungs in liquid nitrogen; we prepared a piece of one lung by the method of Storey and Staub (9) and examined frozen sections for histologic evidence of pulmonary edema.

Analytic methods. We centrifuged samples of lymph and blood and measured the concentration of total protein in the supernates by the Biuret method (10) and albumin and globulin fractions by cellulose-acetate electrophoresis (Microzone 110, Beckman Instruments, Inc., Fullerton, Calif.). We measured arterial oxygen $\left(\mathrm{PaO}_{2}\right)$ and carbon dioxide $\left(\mathrm{PaCO}_{2}\right)$ tensions and $\mathrm{pH}$ at least once during each experiment (acid-base analyzer, Radiometer Co., Copenhagen, Denmark).

For the radioactive tracer studies, we transferred $0.1 \mathrm{ml}$ of each lymph and plasma sample into noncontaminated test tubes, using an Eppendorf microliter pipet (Germany), then counted all samples for $1 \mathrm{~min}$ in a Searle 512 multichannel pulse-height analyzer (Searle Analytic Inc., Des Plaines, Ill.), and calculated the specific activity by dividing the counts per minute by the concentration of albumin in each sample. We constructed a regression line by plotting the ratio of lymph specific activity to plasma specific activity as a function of time after injection, and from that determined the time at which lymph specific activity reached half the plasma specific activity.

Before each ${ }^{125}$ I-albumin experiment, we precipitated a sample of Albumotope (E. R. Squibb \& Sons, Inc., New Brunswick, N. J.) in $20 \%$ trichloracetic acid, centrifuged the specimen, and counted the supernate to ascertain that the ${ }^{125} \mathrm{I}$ was bound to the albumin. In every case, we recovered $<2 \%$ of the radioactivity in the protein-free supernate.

We measured extravascular lung water per gram of dry bloodless lung weight for all lambs by a modification (11, 12) of the method described by Pearce et al. (13), but we made these measurements for only six lambs following baseline experimental conditions, as described above. We killed the other lambs after different types of experiments, which may have altered their extravascular lung water content. In every case, however, we calculated the weight of dry bloodless lung in order to express pulmonary lymph flow and protein flow (lymph flow $\times$ lymph protein concentration) relative to the weight of lung tissue rather than body weight. In addition, we expressed protein flow in relation to the concentration of protein in the plasma of each animal.

Statistics. We averaged the results for all experiments performed on each animal and, in addition, summarized those data by taking the average $\pm 1 \mathrm{SE}$ for measurements made on the 12 lambs. We compared these results to those of previous steady-state base-line experiments on unanesthetized sheep before hypoxia (6) or hyperoxia. We used either the unpaired $t$ test or the nonparametric rank sum test (14) for statistical analysis and accepted $P<0.05$ as indica- 
tive of significant differences. Other data, not directly related to lung fluid and protein transport, are given in the text as the average $\pm 1 \mathrm{SE}$ of the average.

\section{RESULTS}

All lambs stood erect and appeared healthy during experiments. Their $\mathrm{PaO}_{2}$ averaged $78 \pm 3$ torr; $\mathrm{PaCO}_{2}$, $37 \pm 2$ torr; arterial $\mathrm{pH} 7.43 \pm 0.01$; aortic blood pressure, $88 \pm 2 / 54 \pm 2$ torr; pulse rate, $183 \pm 3 / \mathrm{min}$; respiratory rate, $73 \pm 7 / \mathrm{min}$; and mixed venous hematocrit, $27 \pm 1 \%$. These are normal values for unanesthetized week-old lambs (15).

Base-line experiments. Table I lists the important data related to pulmonary fluid filtration and microvascular permeability to plasma proteins. We have compared the results of 27 experiments on 12 lambs to those of 22 experiments on 9 sheep. Ppa was higher in lambs ( $18 \pm 1$ torr) than in sheep (14 \pm 1 torr). Pिla averaged $3 \pm 0.4$ torr in lambs and $1 \pm 0.4$ torr in sheep, a small but significant difference. Both lymph and plasma concentrations of protein were lower in the younger animals.
Lung lymph flow, expressed in terms of dry bloodless lung weight, was $57 \%$ higher, and average protein flow, relative to lung weight and plasma protein concentration, was $32 \%$ higher in lambs than in sheep. The difference in lymph flow was significant; the difference in protein transport was not. The concentration of albumin relative to globulin in both lymph and plasma did not differ for the two groups of animals. The total protein concentration in lymph relative to plasma was lower in the younger animals. In both lambs and sheep, albumin concentration in lymph relative to plasma was higher than that for total protein.

Saline-infusion studies. Fig. 1 illustrates the changes in lymph flow, protein concentrations, and vascular pressures during a typical saline-infusion study. After the 2-h base-line period, the lamb received a rapid, steady infusion of saline, $154 \mathrm{meq} / \mathrm{liter}$ at a rate of $140 \mathrm{ml} / \mathrm{kg}$ per $\mathrm{h}$, for $3.5 \mathrm{~h}$. Lymph flow increased, associated with the elevated vascular pressures and reduced protein concentrations. Cessation of the infusion brought a decrease in lymph flow and vascular pressures, with an increase in plasma protein concentration, but return to the base-line steady state took

TABLE I

Data Pertaining to Pulmonary Lymph Flow and Protein Transport in 12 Lambs and 9 Sheep

\begin{tabular}{|c|c|c|c|c|c|c|c|c|c|c|c|c|c|}
\hline & & & & & & & & & & & Prot & mation & \\
\hline Nun & & & & & & & & & & & & & \\
\hline & & & blood- & Vascular & ressures & concer & ations & & & Albumin & Globulin & Lymp & Plasma \\
\hline Lamb & ments & Body & lung & Pिpa & Ṕla & Lymph & Plasma & flow & flow & Lymph & Plasma & Protein & Albumin \\
\hline & & $\mathrm{kg}$ & $g$ & & & & & $m l / h^{*}$ & $m g / h t$ & & & & \\
\hline 1 & 2 & 7.9 & 26.8 & 16 & 4 & 3.80 & 5.11 & 0.11 & 0.81 & 0.92 & 0.69 & 0.74 & 0.88 \\
\hline 2 & 2 & 4.3 & 12.0 & 18 & 2 & 3.11 & 5.36 & 0.10 & 0.59 & 0.81 & 0.61 & 0.58 & 0.69 \\
\hline 3 & 1 & 4.5 & 12.6 & 23 & 1 & 2.30 & 4.61 & 0.19 & 0.95 & 0.95 & 0.58 & 0.50 & 0.66 \\
\hline 4 & 1 & 6.4 & 23.9 & 13 & 0 & 3.56 & 4.72 & 0.04 & 0.28 & 0.97 & 0.65 & 0.75 & 0.94 \\
\hline 5 & 4 & 7.6 & 35.8 & 19 & 2 & 3.11 & 5.47 & 0.07 & 0.42 & 1.07 & 0.62 & 0.57 & 0.77 \\
\hline 6 & 3 & 5.8 & 19.6 & 20 & 3 & 2.59 & 4.74 & 0.13 & 0.70 & 1.19 & 0.69 & 0.55 & 0.73 \\
\hline 7 & 3 & 6.1 & 18.5 & 19 & 2 & 2.77 & 4.58 & 0.12 & 0.73 & 0.96 & 0.59 & 0.61 & 0.79 \\
\hline 8 & 1 & 5.1 & 19.4 & 19 & 5 & 2.51 & 4.99 & 0.19 & 0.84 & 0.85 & 0.55 & 0.50 & 0.65 \\
\hline 9 & 4 & 6.7 & 33.9 & 16 & 2 & 2.87 & 5.13 & 0.12 & 0.64 & 0.89 & 0.56 & 0.56 & 0.77 \\
\hline 10 & 1 & 5.4 & 16.6 & 17 & 4 & 3.23 & 5.21 & 0.09 & 0.58 & 0.86 & 0.52 & 0.62 & 0.83 \\
\hline 11 & 3 & 4.4 & 25.2 & 19 & 2 & 3.01 & 4.86 & 0.07 & 0.40 & 0.86 & 0.58 & 0.62 & 0.78 \\
\hline 12 & 2 & 7.2 & 19.8 & 18 & 5 & 3.53 & 5.27 & 0.07 & 0.47 & 0.92 & 0.69 & 0.67 & 0.78 \\
\hline ver: & 5 & ve & & & & & & & & & & & \\
\hline Lambs & 27 & $\begin{array}{r}6.0 \\
\pm 0.4\end{array}$ & $\begin{array}{r}22.0 \\
\pm 2.2\end{array}$ & $\begin{array}{r}18 \\
\pm 1\end{array}$ & $\begin{array}{c}3 \\
\pm 0.4\end{array}$ & $\begin{array}{r}3.03 \\
\pm 0.13\end{array}$ & $\begin{array}{r}5.00 \\
\pm 0.09\end{array}$ & $\begin{array}{r}0.11 \\
\pm 0.01\end{array}$ & $\begin{array}{r}0.62 \\
\pm 0.06\end{array}$ & $\begin{array}{r}0.94 \\
\pm 0.03\end{array}$ & $\begin{array}{r}0.60 \\
\pm 0.02\end{array}$ & $\begin{array}{r}0.61 \\
\pm 0.02\end{array}$ & $\begin{array}{r}0.77 \\
\pm 0.03\end{array}$ \\
\hline Sheep & 22 & $\begin{array}{r}49.6 \\
\pm 1.5\end{array}$ & $\begin{array}{r}94.6 \\
\pm 2.7\end{array}$ & $\begin{array}{r}14 \\
\pm 1\end{array}$ & $\begin{array}{c}1 \\
\pm 0.4\end{array}$ & $\begin{array}{r}4.23 \\
\pm 0.13\end{array}$ & $\begin{array}{r}6.14 \\
\pm 0.09\end{array}$ & $\begin{array}{r}0.07 \\
\pm 0.01\end{array}$ & $\begin{array}{r}0.47 \\
\pm 0.08\end{array}$ & $\begin{array}{r}1.01 \\
\pm 0.10\end{array}$ & $\begin{array}{r}0.62 \\
\pm 0.04\end{array}$ & $\begin{array}{r}0.69 \\
\pm 0.02\end{array}$ & $\begin{array}{r}0.89 \\
\pm 0.02\end{array}$ \\
\hline$P$ & & $<0.05$ & $<0.05$ & $<0.05$ & $<0.05$ & $<0.05$ & $<0.05$ & $<0.05$ & NS & NS & NS & $<0.05$ & $<0.05$ \\
\hline
\end{tabular}

Results are average measurements of all experiments in each lamb.

* Per gram of dry bloodless lung.

$\$$ Per gram of dry bloodless lung, per gram of plasma proteins $\times \mathrm{dl}^{-1}$. 


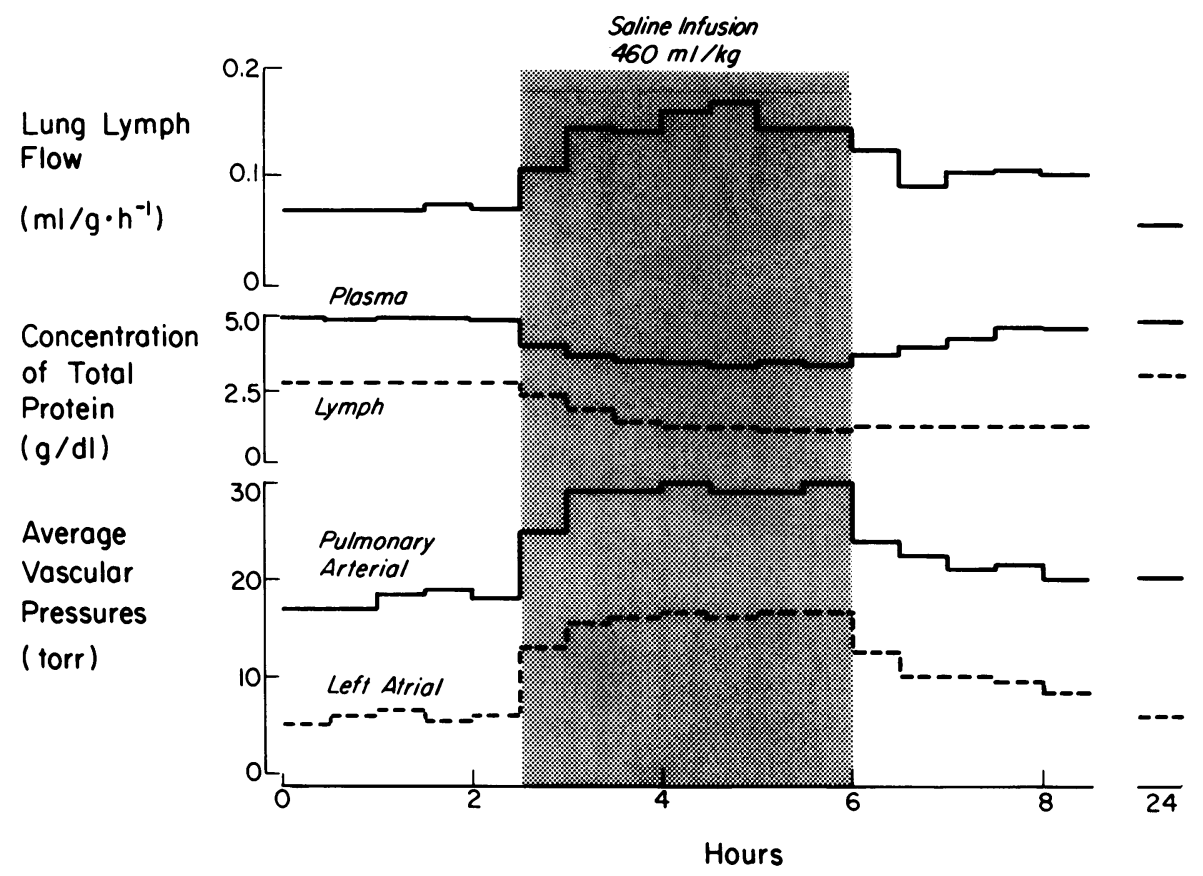

FIGURE 1. Pulmonary lymph flow, protein concentrations, and average vascular pressures under steady-state conditions, before, during, and after an infusion of saline solution, $154 \mathrm{meq} / \mathrm{l}$, into the right atrium of a lamb. Measurements made $24 \mathrm{~h}$ later are shown for completeness. Lymph flow is related to gram of dry bloodless lung tissue.

several hours. Table II shows the results of three such experiments, demonstrating the consistency of the changes. The saline infusions did not alter significantly the ratio of albumin concentration to globulin concentration in either lymph or plasma.

Tracer studies. Fig. 2 illustrates the time-course of

TABLE II

Steady-State Pulmonary Vascular Pressures, Lymph Flow, and Protein Concentrations in Three Lambs before and after Intravenous Infusion of Saline Solution, 154 meq/liter

\begin{tabular}{|c|c|c|c|c|c|c|c|c|c|}
\hline & & \multirow{3}{*}{$\begin{array}{l}\text { Infusion } \\
\text { rate }\end{array}$} & \multirow{2}{*}{\multicolumn{2}{|c|}{$\begin{array}{l}\text { Vascular } \\
\text { pressures }\end{array}$}} & \multirow{3}{*}{$\begin{array}{l}\text { Lymph } \\
\text { flow }\end{array}$} & \multicolumn{4}{|c|}{ Protein concentrations } \\
\hline & & & & & & \multicolumn{2}{|c|}{ Lymph } & \multicolumn{2}{|c|}{ Plasma } \\
\hline & & & Pिpa & Pिla & & Albumin & Globulin & Albumin & Globulin \\
\hline & & $m g / k g h$ & \multicolumn{2}{|c|}{ torr } & $m l / h^{*}$ & \multicolumn{4}{|c|}{$g / d l$} \\
\hline \multicolumn{10}{|l|}{ Lamb } \\
\hline \multirow[t]{2}{*}{10} & Baseline & & 17 & 4 & 0.09 & 1.49 & 1.74 & 1.79 & 3.42 \\
\hline & Saline & 140 & 34 & 12 & 0.21 & 0.99 & 1.17 & 1.38 & 2.35 \\
\hline \multirow[t]{2}{*}{11} & Baseline & & 15 & 3 & 0.08 & 1.51 & 1.62 & 1.72 & 3.10 \\
\hline & Saline & 250 & 33 & 13 & 0.16 & 0.77 & 0.82 & 1.30 & 2.48 \\
\hline \multirow[t]{2}{*}{12} & Baseline & & 18 & 6 & 0.07 & 1.56 & 1.63 & 2.09 & 2.91 \\
\hline & Saline & 130 & 30 & 16 & 0.16 & 0.99 & 0.80 & 1.56 & 2.07 \\
\hline \multirow{4}{*}{$\begin{array}{c}\text { Average } \pm S E \text { of } \\
\text { the average }\end{array}$} & & & & & & & & & \\
\hline & Baseme & & \pm 1 & $\begin{array}{r}4 \\
\pm 1\end{array}$ & $\begin{array}{r}0.00 \\
\pm 0.01\end{array}$ & $\begin{array}{r}1.52 \\
\pm 0.02\end{array}$ & $\begin{array}{r}1.66 \\
\pm 0.04\end{array}$ & $\begin{array}{r}1.81 \\
\pm 0.11\end{array}$ & $\begin{array}{r}3.14 \\
\pm 0.15\end{array}$ \\
\hline & Saline & & 32 & 14 & 0.18 & 0.92 & 0.93 & 1.41 & 2.30 \\
\hline & & & \pm 1 & \pm 1 & \pm 0.02 & \pm 0.07 & \pm 0.12 & \pm 0.08 & \pm 0.12 \\
\hline
\end{tabular}

* Per gram of dry bloodless lung.

1110 R. Bland and D. McMillan 

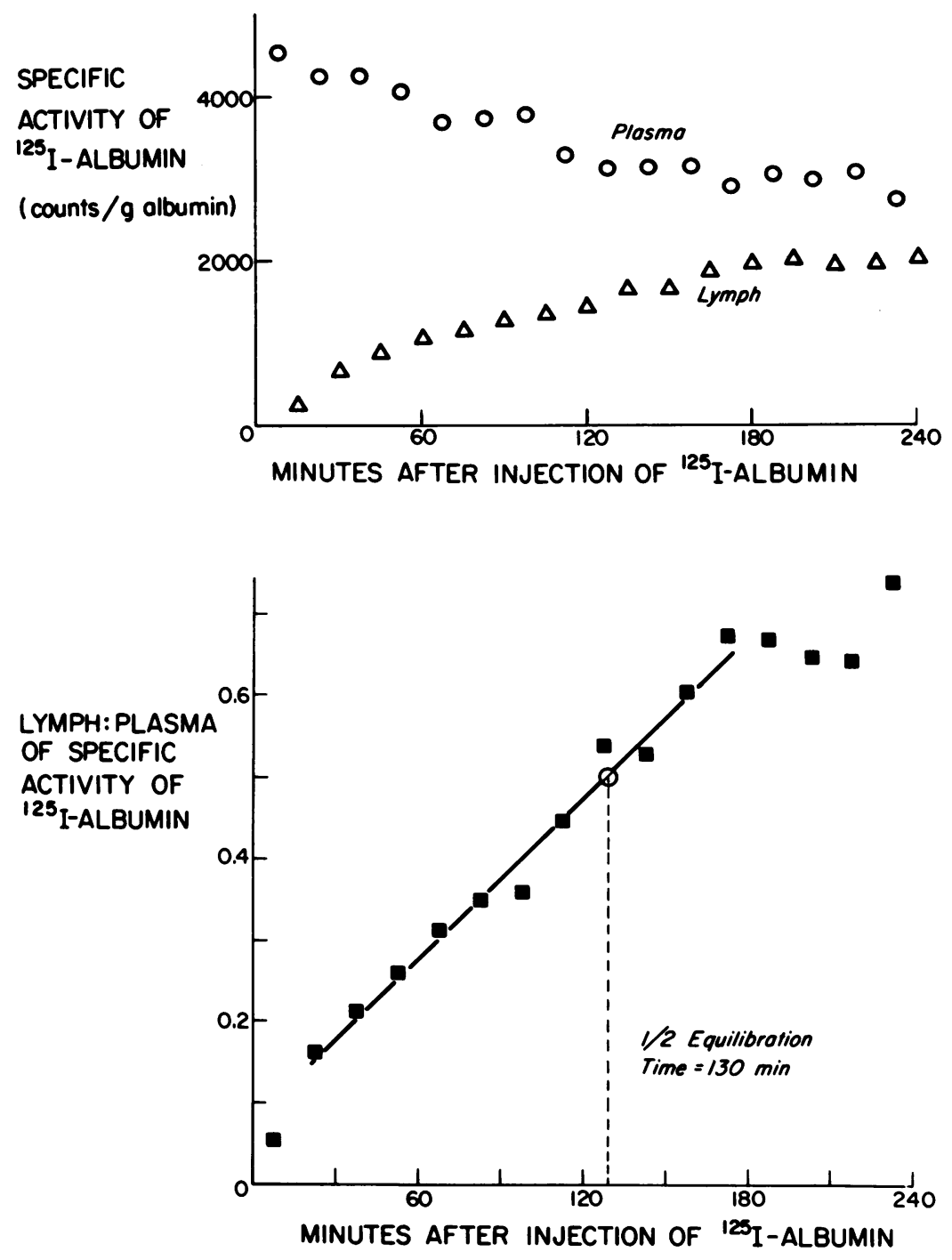

FIgURE 2 Lamb 5. (Top) Decrease of plasma specific activity (circles) and increase of lymph specific activity (triangles) after injection of $50 \mu \mathrm{Ci}(7 \mu \mathrm{Ci} / \mathrm{kg})$ of ${ }^{125} \mathrm{I}$-albumin into the right atrium. Equilibration began 2-3 h after the injection. (Bottom) For the same experiment, lymph:plasma specific activity of ${ }^{125}$ I-albumin as a function of time after injection; regression line crosses the half-equilibration (0.5) point at $130 \mathrm{~min}$ (half-equilibration time).

one base-line experiment in which we injected ${ }^{125} \mathrm{I}$ albumin into the right atrium of a lamb. The top part shows the typical decrease of plasma specific activity and the increase of lymph specific activity with time. In 11 such studies performed on eight lambs whose Pिpa averaged 20 torr and Pिla, 3 torr, half-equilibration occurred $101 \pm 8$ min after injection of the radioactive tracer, significantly faster than in sheep studied in a similar fashion by Vaughan et al. (16).

Postmortem findings. Extravascular lung water per gram of dry bloodless lung was significantly greater in lambs $(4.82 \pm 0.11 \mathrm{~g})$ than in sheep $(4.45 \pm 0.08 \mathrm{~g})$. We saw no evidence of pulmonary edema in the four histologic sections of frozen lung which we examined.
Fig. 3 demonstrates the typical appearance of the inflated lungs of a lamb and a sheep, with no intraalveolar or perivascular interstitial fluid.

The weight of dry bloodless lung averaged $22.0 \pm 2.2$ $\mathrm{g}$ in lambs compared with $94.6 \pm 2.7 \mathrm{~g}$ in sheep. This fourfold difference in lung tissue mass is noteworthy, because the average body weight of sheep was more than eight times that of lambs.

\section{DISCUSSION}

Previous work by Staub and associates demonstrated that measurement of pulmonary lymph flow and protein concentration is a sensitive method for detecting dif- 

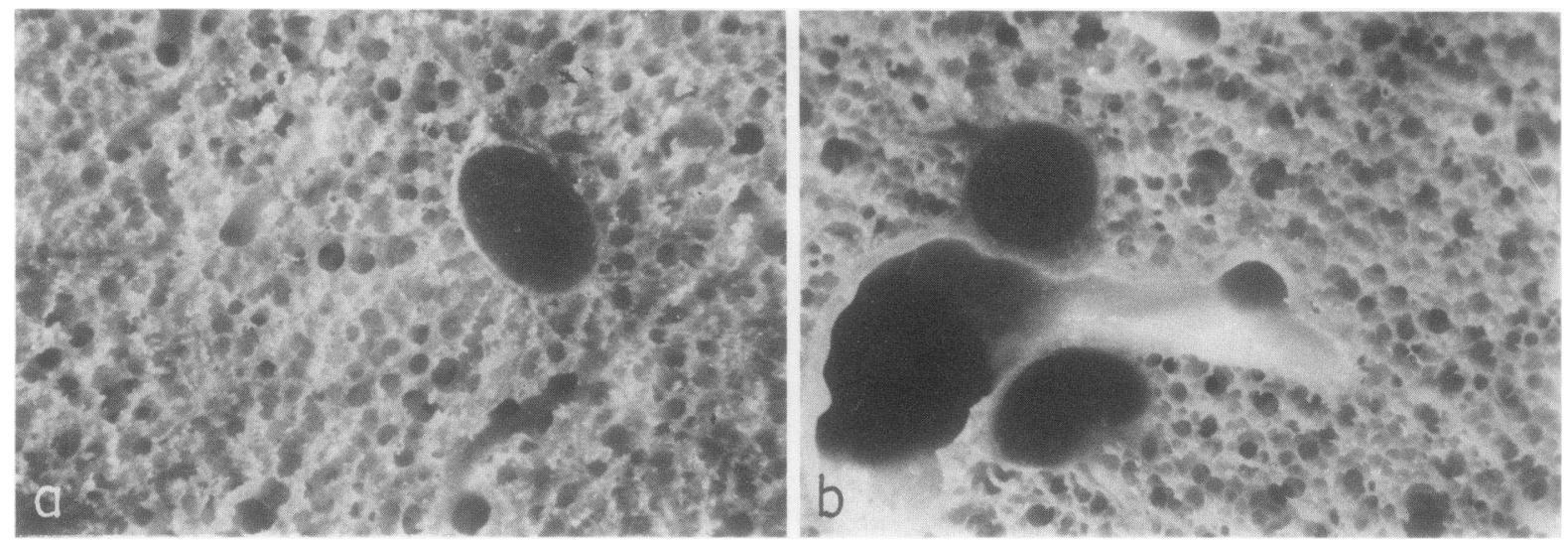

FIGURE 3 Sections of frozen lung obtained at an inflation pressure of $25 \mathrm{cmH}_{2} \mathrm{O}$ from a 10-day-old lamb (a) and a sheep (b). Magnification is $\times 8.5$. Note the normal lung architecture, with absence of intra-alveolar and perivascular fluid in both sections.

ferences in net transvascular movement of fluid and protein in the lung $(6-8,11,12,17,18)$, assuming that the protein concentration of lung lymph closely approximates that of pulmonary interstitial fluid. Two recent studies offer strong support for that assumption: Vreim et al. (19) found that the protein concentration of lung lymph was almost identical to that of free interstitial fluid in sheep with pulmonary edema, and Nicolaysen et al. (20) discovered no change in the concentration of albumin flowing within lymphatic channels of normal mouse lungs, suggesting that lymphatics neither dilute nor concentrate protein in the lung.

Inasmuch as the thoracic duct receives appproximately the same proportion of pulmonary lymph drainage via the caudal mediastinal lymph node in lambs and sheep $(3,8)$, we considered it appropriate to compare the composition and flow rate of lymph emanating from that node in lambs vs. sheep. Our animal preparation and experimental protocol have many advantages over previous designs to define lung fluid filtration and microvascular permeability to protein in newborn animals. The lambs were awake and unrestrained, without the abiding influence of surgery and anesthesia to muddle interpretation of results; we measured pulmonary vascular pressures and lymph flow simultaneously, enabling us to distinguish differences in fluid filtration from differences in microvascular permeability to protein; and by deriving the weight of dry lung tissue, exclusive of blood, from postmortem measurements, we could express lymph flow and lymph protein flow relative to their tissue of origin rather than body weight.

The important relationships that affect filtration of fluid in the lung are the pulmonary transvascular gradients of hydraulic and protein osmotic pressures. The higher Pिpa and Pिla of lambs, compared with sheep, and their lower ratio of protein concentration in lymph relative to that in plasma, suggest that pulmonary microvascular hydraulic pressure was greater in the younger animals. Extravascular hydraulic pressure is not measurable, but there is no reason to suspect a difference in tissue pressure between healthy lambs and sheep, as their respiratory frequencies and pattern of breathing are similar (6). Our measurements of protein concentration in lymph and plasma demonstrate that intravascular protein osmotic pressure, derived from the curve of Landis and Pappenheimer (21), was lower in lambs than in sheep, a finding which Guyton and Lindsay (22) observed may facilitate pulmonary edema. Though the difference between plasma and lymph concentrations of protein was greater in lambs than in sheep, the calculated transvascular difference (plasma minus lymph) for protein osmotic pressure was 1 torr greater in sheep than in lambs. This is because the relationship between plasma protein concentration and protein osmotic pressure is nonlinear; that is, osmotic pressure per gram of plasma protein is less at lower than at higher protein concentrations (21).

These differences favor greater filtration of fluid across the pulmonary vascular endothelium of lambs; therefore, it is not surprising that more lymph flowed from lambs than from sheep (relative to dry bloodless lung weight). As expected in the presence of increased lymph flow, average protein flux out of the circulation, in relation to lung weight and plasma protein concentration, also was greater in lambs, though this difference was not significant.

Comparing ratios of albumin and globulin in lymph and plasma of lambs and sheep may help to distinguish differences in fluid filtration from differences in membrane permeability. Brigham and Owen (23) found that the ratio of the concentration of albumin to that of globulin in pulmonary lymph of sheep did not change significantly when Pिla was increased by an average of 
11 torr; in the same animals, they demonstrated a decrease in the albumin: globulin ratio in five of six sheep given histamine, an agent which they showed increases pulmonary microvascular permeability to plasma proteins. The fact that the concentration of albumin relative to globulin in both lymph and plasma was almost identical in lambs and sheep suggests that molecular sieving across the vascular endothelium did not differ appreciably in the two groups of animals.

Brigham et al. (11) showed that elevating vascular hydraulic pressure in the presence of increased microvascular permeability augments pulmonary lymph flow to a much greater extent than when normal permeability exists. We raised vascular pressures in three lambs by rapidly infusing saline into the right atrium; lymph flow increased, just as it did in four sheep (6) when we elevated pulmonary microvascular pressure by inflating a balloon in the left atrium.

Fig. 4 shows that the sum of the transvascular pressure gradients under base-line conditions was

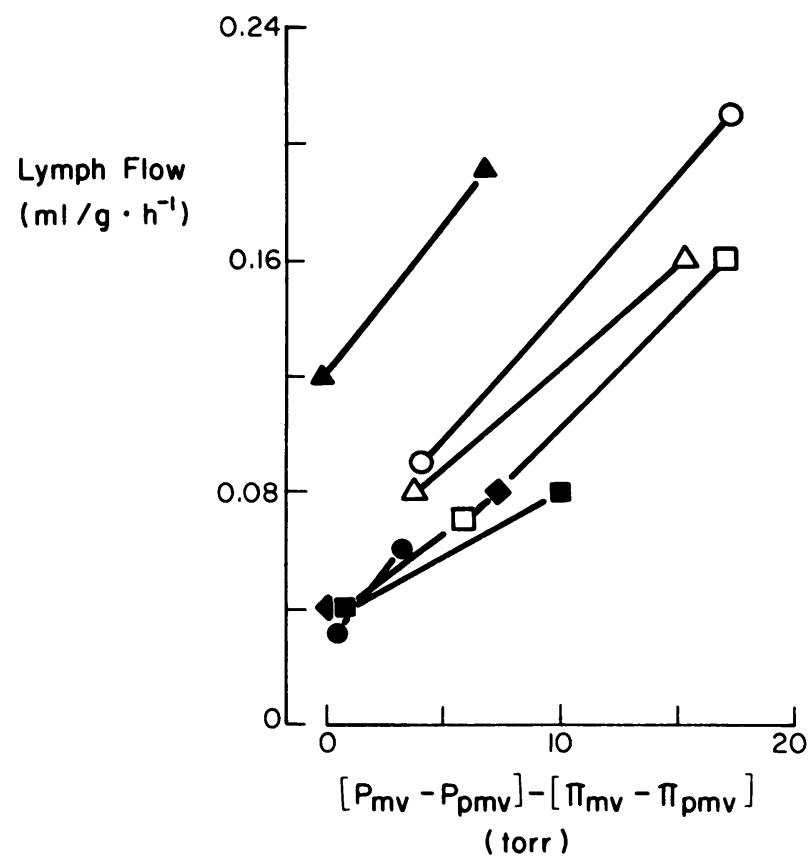

FIGURE 4 Lymph flow measurements as a function of transvascular driving pressure in three lambs (open symbols) and four sheep (closed symbols) under base-line conditions and after saline infusion (lambs) or inflation of a balloon in the left atrium (sheep). Average pulmonary microvascular pres-

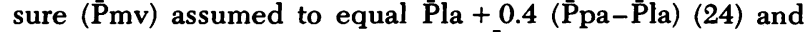
average perimicrovascular pressure ( $\overline{\mathrm{P}} \mathrm{pmv})$ assumed to equal atmospheric pressure. All hydraulic pressure measurements were in reference to the level of the left atrium. Protein osmotic pressure of plasma (Пmv) and lung interstitium (Пpmv) derived from equations of Landis and Pappenheimer (21), based on measurements of protein concentration in plasma and lymph of lambs and sheep. greater in lambs than in sheep; the sum of pressures increased more after saline infusions to lambs than after balloon tamponade of the left atrium in sheep; but the rate of change in lymph flow as a function of transvascular pressure was almost identical in lambs and sheep, indicated by the slope of the lines (average of $0.008 \mathrm{ml} / \mathrm{g}$ per $\mathrm{h}$ per torr for both). The difference in the evoked pressure gradients between lambs and sheep is at least partly the effect of our methods of raising microvascular pressure-infusions of saline lead to hemodilution of the plasma and thereby decrease the transvascular gradient for protein osmotic pressure, whereas inflation of a balloon in the left atrium induces hemoconcentration of the plasma (12), causing an increase in the transvascular gradient for protein osmotic pressure. The results of these seven studies again emphasize the similarity between the permeability-surface area product of the pulmonary microvascular membrane in lambs and sheep.

It is noteworthy that intravenous infusions of furosemide decreased lung lymph flow and lymph protein flow of lambs to rates approximating those measured in sheep under base-line conditions (25). This decline in lymph and protein flow accompanied a $10 \%$ increase in the concentration of plasma proteins and a decrease of Pla to 1 torr, changes induced by hemoconcentration from diuresis. These observations underscore the importance that small differences in transvascular pressures may have on lung fluid filtration and lymph flow in lambs.

Enhanced protein permeability of the microcirculation in the lung implies that the flow of protein across the endothelium into the interstitial space increases out of proportion to the increase of liquid flow. In previous experiments performed on 39 sheep $(6,11,12,22,26)$, Pla was elevated by inflation of a balloon in the left atrium; the resulting increase of protein flow (Q́prrelated to the concentration of protein in plasma) was $47 \%$ of the increase in lymph flow (Q́lym). In other words, the ratio of the difference in protein flow to the difference in lymph flow $(\Delta \dot{Q} \mathrm{pr} / \Delta \dot{\mathrm{Q}} \mathrm{lym})$ was 0.47 , with a $S D$ of 0.18 . Microvascular permeability to plasma proteins was enhanced in 13 of the same sheep by infusions of Pseudomonas aeruginosa (11) or histamine (25), resulting in a $\Delta \dot{\mathrm{Q} p r} / \Delta \mathrm{Q}$ lym of 0.93 \pm 0.21 . If we compare our data for Qpr and Q lambs and sheep, $\Delta \dot{Q} \mathrm{pr} / \Delta \dot{\mathrm{Q}} \mathrm{lym}$ is 0.57 , again most consistent with a pressure-evoked difference in fluid filtration.

Our finding that total protein concentration in lymph relative to plasma was lower in the younger animals is consistent with a greater transvascular hydraulic pressure gradient in lambs than sheep, producing more filtration of fluid. The observation that albumin concentration in lymph relative to plasma was higher than that of total protein in both lambs and sheep empha- 
sizes the fact that irrespective of maturity, albumin traverses the vascular endothelium more rapidly than the larger globulin molecules.

Humphreys et al. (3) noted that the concentration of proteins in lymph and plasma was higher in lambs than in sheep. Boyd et al. (4) reported that the concentration of both albumin and globulin in lymph relative to plasma was greater in newborn than in older sheep. They did not measure pulmonary vascular pressures. We cannot explain the striking discrepancy between their results and ours, but they would appear to reflect a substantial difference in hydration. We have not discovered a single lamb with a plasma protein concentration of greater than $8 \mathrm{~g} / \mathrm{dl}$, which Humphreys et al. (3) reported as the average concentration for newborn lambs in their studies.

Based on their data, these investigators derived a pulmonary microvascular pore radius of $90 \AA$ for lambs, compared with $130 \AA$ for older sheep; they calculated the pore area per unit path length of pulmonary capillaries in lambs to be $16 \frac{1}{2}$ times greater than that in sheep (4). To achieve these differences in the presence of the aforementioned pore radii, Boyd et al. concluded that the net filtration pressure in newborn lambs would have been approximately 4 torr compared with 26 torr in sheep. We regard this large difference in estimated filtration pressure as unlikely, in light of our own steady-state measurements of Pिa, Pla, protein concentrations, and lymph flow in unanesthetized lambs and sheep.

From these measurements, we conclude that there is a larger net transvascular filtration pressure in lambs than sheep, driving more fluid into the interstitium of the lung, with a small secondary increase in the bulk flow of protein. Our observation of more extravascular lung water per gram of dry bloodless lung in lambs than in sheep is consistent with that interpretation.

But how should we interpret the more rapid movement of a radioactive protein tracer from the pulmonary microcirculation into the lung interstitium of lambs than of sheep? Inasmuch as the size of the sites for pulmonary transvascular protein movement in lambs and sheep appears to be similar, we conclude that the more rapid equilibration of ${ }^{125} \mathrm{I}$-albumin in lambs was the result of $(a)$ a greater pulmonary transvascular gradient of hydraulic pressure, with increased lymph flow and bulk protein flow, and (b) more cross-sectional area for transvascular protein exchange relative to the volume of distribution of the protein in the lung, i.e., either more pulmonary blood vessels participated in protein exchange, or there were more pores per unit of vascular surface area in lambs than in sheep, or the extravascular space accessible to protein was smaller relative to microvascular surface area in the younger animals. Our results cannot differentiate those possibilities.
Finally, we must explain why other investigators have found a three- to fourfold difference in lymph flow between lambs and sheep in acute experiments (2-4), compared with the $57 \%$ difference we are reporting. Although there was an eightfold difference in body weight between lambs and sheep, the lung tissue of the lambs was only one-fourth the mass of lung tissue of the sheep. Therefore, if we relate lymph flow to body weight, as Strang and his co-workers did (2-4), the difference is more than $200 \%$, much greater than if we relate lymph flow to dry bloodless lung tissue, perhaps a more appropriate index of pulmonary transvascular fluid filtration. Likewise, relative to body weight, protein flow in lambs was $154 \%$ greater than in sheep; in relation to dry lung tissue, the difference was small and not statistically significant.

We would prefer to express pulmonary lymph flow in relation to pulmonary microvascular surface area, rather than dry bloodless lung weight, but there is no available data regarding the relationship of pulmonary microvascular surface area to body weight during postnatal development of sheep (27). In morphologic studies of rats, however, Burri et al. (28) found that specific lung volume (lung volume/body weight) decreased significantly from 1 to 131 days of age. This decrease was comparable to our observation of a lower specific lung weight in adult sheep than in newborn lambs. Furthermore, Burri et al. discovered an almost linear and identical relationship of capillary surface area and alveolar surface area to lung volume. If we assume that postnatal lung development in the rat parallels that in the lamb, then it would appear that dry bloodless lung weight is more suitable than body weight as an index of pulmonary lymph flow.

We conclude that fluid filtration in the lung of newborn lambs is greater per unit lung mass than in adult sheep. Our data regarding protein transport suggest that the size of the individual sites for transvascular protein exchange is not altered appreciably by postnatal growth and maturity. The absolute area available for protein exchange in lambs is comparable to the area in sheep, but relative to the volume of distribution of the protein, the exchange area is greater in newborn lambs than in adult sheep.

\section{ACKNOWLEDGMENTS}

We thank Doctors John Clements, Abraham Rudolph, Norman Staub, and William Tooley for their helpful advice, Mr. Luther Dong for his technical assistance, and Mrs. Marilyn Biagini for her secretarial help.

This work was supported in part by National Heart and Lung Institute Pulmonary Specialized Center of Research grants HL 14201 and HL 19185 and by a grant from the California Lung Association. Dr. McMillan received support from the Canadian Cystic Fibrosis Foundation.

\section{4 \\ R. Bland and D. McMillan}




\section{REFERENCES}

1. Taylor, P. M., U. Boonyaprakob, V. Waterman, D. Watson, and E. Lopata. 1967. Clearances of plasma proteins from pulmonary vascular beds of adult dogs and pups. Am.J. Physiol. 213: 441-449.

2. Boston, R. W., P. W. Humphreys, E. O. R. Reynolds, and L. B. Strang. 1965. Lymph-flow and clearance of liquid from the lungs of the foetal lamb. Lancet. II: 473-474.

3. Humphreys, P. W., I. C. S. Normand, E. O. R. Reynolds, and L. B. Strang. 1967. Pulmonary lymph flow and the uptake of liquid from the lungs of the lamb at the start of breathing. J. Physiol. (Lond.). 193: 1-29.

4. Boyd, R. D. H., J. R. Hill, P. W. Humphreys, I. C. S. Normand, E. O. R. Reynolds, and L. B. Strang. 1969. Permeability of lung capillaries to macromolecules in foetal and new-born lambs and sheep. J. Physiol. (Lond.). 201: 567-588.

5. Levine, O. R., F. Rodrigues-Martinez, and R. B. Mellins. 1973. Fluid filtration in the lung of the intact puppy. J. Appl. Physiol. 34: 683-689.

6. Bland, R. D., R. H. Demling, S. L. Selinger, and N. C. Staub. 1977. Effects of alveolar hypoxia on lung fluid and protein transport in unanesthetized sheep. Circ. Res. 40: 269-274.

7. Staub, N. C., R. D. Bland, K. L. Brigham, R. H. Demling, A. J. Erdmann, III, and W. C. Woolverton. 1975. Preparation of chronic lung lymph fistulas in sheep. J. Surg. Res. 19: 315-320.

8. Vaughan, T. R., Jr., A. J. Erdmann, III, K. L. Brigham, W. C. Woolverton, and N. C. Staub. 1972. Total lung lymph flow and interstitial albumin distribution. Clin. Res. 20: 583.

9. Storey, W. F., and N. C. Staub. 1962. Ventilation of terminal air units. J. Appl. Physiol. 17: 179-183.

10. Gornall, A. G., C. J. Bardawill, and M. M. David. 1949. Determination of serum proteins by means of the Biuret reaction. J. Biol. Chem. 177: 751-766.

11. Brigham, K. L., W. C. Woolverton, L. H. Blake, and N. C. Staub. 1974. Increased sheep lung vascular permeability caused by pseudomonas bacteremia. J. Clin. Invest. 54: 792-804.

12. Erdmann, A. J., III, T. R. Vaughan, Jr., K. L. Brigham, W. C. Woolverton, and N. C. Staub. 1975. Effect of increased vascular pressure on lung fluid balance in unanesthetized sheep. Circ. Res. 37: 271-284.

13. Pearce, M. L., J. Yamashita, and J. Beazell. 1965. Measurement of pulmonary edema. Circ. Res. 16: 482-488.

14. Snedecor, G., and W. Cochran. 1967. Statistical Methods.
Iowa State University Press, Ames, Iowa. 6th edition. $593 \mathrm{pp}$.

15. Klopfenstein, H. S. 1975. The development of myocardial performance in lambs. Ph.D. thesis, University of California, San Francisco. 1-48.

16. Vaughan, T. R., Jr., A. J. Erdmann, III, K. L. Brigham, W. C. Woolverton, and N. C. Staub. 1974. Pulmonary transcapillary albumin flow: effect of high pressure and increased permeability. Am. Rev. Respir. Dis. 109: 692693.

17. Staub, N. C. 1971. Steady state pulmonary transvascular water filtration in unanesthetized sheep. Circ. Res. 1 (Suppl. 28/29): 135-139.

18. Staub, N. C. 1974. Pulmonary edema. Physiol. Rev. 54: $678-811$.

19. Vreim, C. E., P. D. Snashall, R. H. Demling, and N. C. Staub. 1976. Lung lymph and free interstitial fluid protein composition in sheep with edema. Am. J. Physiol. 230: 1650-1653.

20. Nicolaysen, G., A. Nicolaysen, and N. C. Staub. 1975. A quantitative radioautographic comparison of albumin concentration in different sized lymph vessels in normal mouse lungs. Microvasc. Res. 10: 138-152.

21. Landis, E. M., and J. R. Pappenheimer. 1963. Exchange of substances through the capillary walls. Handb. Physiol. 2 (Sect. 2. Circulation): 961-1034.

22. Guyton, A. C., and A. W. Lindsay. 1959. Effect of elevated left atrial pressure and decreased plasma protein concentration on the development of pulmonary edema. Circ. Res. 7: 649-657.

23. Brigham, K. L., and P. J. Owen. 1975. Mechanism of the serotonin effect on lung transvascular fluid and protein movement in awake sheep. Circ. Res. 36: 761-770.

24. Gaar, K. A., A. E. Taylor, L. J. Owens, and A. C. Guyton. 1967. Pulmonary capillary pressure and filtration coefficient in the isolated perfused lung. Am. J. Physiol. 213: 910-914.

25. Bland, R. D., D. D. McMillan, and W. H. Tooley. 1976. Dose-dependent decrease of pulmonary transvascular fluid filtration in awake newborn lambs after intravenous furosemide. Clin. Res. 24: 382A. (Abstr.)

26. Brigham, K. L., and P. J. Owen. 1975. Increased sheep lung vascular permeability caused by histamine. Circ. Res. 37: 647-657.

27. Thurlbeck, W. M. 1975. Postnatal growth and development of the lung. Am. Rev. Respir. Dis. 3: 803-844.

28. Burri, P. H., J. Dbaly, and E. R. Weibel. 1974. The postnatal growth of the rat lung. I. Morphometry. Anat. Rec. 178: $711-730$. 